\title{
Imparting Biocidal Properties to Wool Fabrics Using Salicylanilide Derivatives
}

\author{
A. Abou El-Kheir, S. Mowafi, M. Salama ${ }^{\#}$, A. A. El-Sayed \\ and A. Kantouch \\ Textile Research Division, National Research Centre, Cairo, \\ Egypt.
}

\begin{abstract}
Production of biocidal fabrics, required by many consumers, is one of the interesting properties nowadays. Imparting a permanent biocidal property to wool fabrics was achieved through the reaction of wool with a synthesized biocidal compound namely 2-(4,6-dichloro1,3,5-triazin-2-yloxy)-N-phenylbenzamide (reactive salicylanilide). Reactive salicylanilide was prepared through the reaction of 2,4,6Trichloro-1,3,5-triazine and salicylanilide. The reaction mechanism was proposed and supported by FTIR. The reaction between wool and the synthesized biocidal agent, with regard to agent concentration, treatment $\mathrm{pH}$, time and temperature were assessed spectrophotometrically. Antimicrobial properties as well as insect resistance of the treated wool fabrics were assessed quantitatively.
\end{abstract}

Keywords: Salicylanilide, Wool fabric, Antimicrobial Activity and Moth proofing.

Textiles have been recognized as media to support the growth of microorganisms such as bacteria and fungi ${ }^{(1)}$. Most synthetic fibers, due to their high hydrophobic property, are more resistant to attack by microorganisms than natural fibers. Proteins in keratinous fibers as well as carbohydrates in cotton can act as nutrients and energy sources under certain conditions ${ }^{(2)}$. Estimations have shown that the production of antimicrobial textiles is in the magnitude of 30,000 tones in Western Europe and 100,000 tonnes worldwide in $2000^{(2)}$.

There are two general categories of technologies, which can provide protection for medical/ healthcare/hygiene personnel. The first one involves the formation of a physical barrier against microbial infiltration or transmission; and the second type of technologies involves the incorporation of active functional agents onto fabrics or fibers ${ }^{(3)}$.

Many contemporary antimicrobial agents are used in textiles, such as quaternary ammonium compounds, N-halamines, chitosan, polybiguanides, triclosan, nanoparticles of noble metals and metal oxides, bioactive plant-based products and polymer antimicrobial. According to their mechanism of antimicrobial activity, toxicity, durability and ecological acceptability. These agents can be divided into biocides and biostats, leaching and bound 
antimicrobials, controlled-release, barrier-forming agents and agents of poor and good washing resistance ${ }^{(4,5)}$.

Wool can be a suitable medium for growing bacteria and fungi under favorable temperature and humidity conditions, resulting in wool degradation ${ }^{(6,7)}$. For this reason, woolen materials have to be protected against microorganisms, in order to avoid their growth and dissemination as well as fiber damage. Inorganic, organic and natural antibacterial finishes have been applied on wool fiber ${ }^{(2,8-14)}$.

Salicylanilide was introduced in 1930 as a fungistat for use on textiles ${ }^{(15)}$. By 1950, salicylanilide became an important mildew-proofing compound for textile fabrics ${ }^{(16)}$. Many of salicylanilide derivatives have been also used as microbicidal agents ${ }^{(17-19)}$.

In this work, the antimicrobial and antifungal properties of wool fabric treated with reactive salicylanilide were studied. The effectiveness and durability of the antimicrobial agent were also investigated.

Materials and chemicals

\section{Experimental}

Plain weave pure Australian merino wool fabric $\left(190 \mathrm{~g} / \mathrm{m}^{2}\right)$ supplied by Spinning and Weaving Company, Mehalla El Kobra, Egypt, was used.

Salicylanilide (98\%) was purchased from Alfa Aesar GmbH \& Co. KG., 2,4,6-Trichloro-1,3,5-triazine was purchased from Aldrich, Steinheim, Germany and Egyptol PLM, nonionic detergent based on nonyl phenol ethoxylate; was supplied from Starch and Brewer's Company, Alexandria, Egypt. All other chemicals are of laboratory grade and used without further purification.

Supranol Brilliant Blue BLW (C.I. Acid Blue 203) was supplied by Egypt Colours Company, Cairo, Egypt.

\section{Procedures}

Wool scouring

Wool fabrics were scoured at $50^{\circ} \mathrm{C}$ using $1.0 \mathrm{~g} / \mathrm{l}$ nonionic detergent in presence of $1.0 \mathrm{~g} / \mathrm{l}$ sodium carbonate $(30 \mathrm{~min}$, liquor ratio $1: 50$ ) to remove superficial fatty matters, which act as barrier for any subsequent wet processing. Woolen fabrics were then rinsed several times with distilled water, squeezed and air-dried.

Synthesis of 2-(4,6-dichloro-1,3,5-triazin-2-yloxy)-N-phenylbenzamide

$9.22 \mathrm{~g}$ (0.05 mole) of 2,4,6-trichloro-1,3,5-triazine (TCTA), dissolved in $55 \mathrm{ml}$ of acetone, The solution was cooled down to $0-5^{\circ} \mathrm{C}$.

$10.66 \mathrm{~g}$ ( 0.05 mole) of salicylanilide was prepared by dissolving in $25 \mathrm{ml}$ of acetone and added slowly to TCTA solution with continuous stirring. The $\mathrm{pH}$ of the reaction mixture was raised to $\mathrm{pH} 6$ using $20 \%$ sodium carbonate solution.

Egypt. J. Chem. 56, No. 5,6 (2013) 
The reaction was left to continue for $1 \mathrm{hr}$ at $0^{\circ} \mathrm{C}$ with stirring. A white grey precipitate of reactive 2- [4,6,- dichloro- 1,3,5- triazine-2- yloxy] - N- phenylbenzamide (reactive salicylanilide) was formed after an hour. The precipitate was collected, washed several times with acetone and then air-dried. Condensation of salicylanilide with cyanuric chloride has been reported ${ }^{(17)}$. The yield was about $45 \%$.

Treatment of wool fabric with reactive salicylanilide

Scoured wool fabric was treated with different concentrations of the reactive salicylanilide (1-5\% o.w.f) at different $\mathrm{pH}$ values $(3-8 \mathrm{pH})$ using exhaustion technique. The reaction was kept to proceed at $80^{\circ} \mathrm{C}$ for an hour, after that the wool fabrics were rinsed thoroughly with running water and left to dry at ambient temperature. The amount of reactive salicylanilide consumed by wool fabric, was assessed spectrophotometrically using JENWAY 6800 UV/visible spectrophotometer. Adding on $\%$ value was calculated by measuring the difference in light absorbance before and after treatment at $\lambda_{\max }(268 \mathrm{~nm})$ according to Equation 1:

$$
\text { Add on } \%=\frac{A_{\text {before }}-A_{\text {after }}}{A_{\text {before }}} \times 100
$$

where:

$A_{\text {before }}=$ the absorbance before treatment.

$A_{\text {affer }}=$ the absorbance after treatment

The following Equation 2 also calculate the amount of reactive salicylanilide absorbed by the fabric ( $\mathrm{g} / 100 \mathrm{~g}$ wool):

where:

$$
M=A \times B \times 100
$$

$\mathrm{M}=$ The amount of reactive salicylanilide absorbed by the fabric ( $\mathrm{g} / 100 \mathrm{~g}$ wool)

$\mathrm{A}=$ Add on $\%$

$\mathrm{B}=$ Conc. of reactive salicylanilide (\% o.w.f.)

\section{Measurements}

Infrared spectroscopy

FTIR spectroscopy of Salicylanilide, 2,4,6-Trichloro-1,3,5-triazine and reactive salicylanilide was measured using a Nicolet 60 SXR Fourier Transform Infrared Spectrometer in the attenuated total reflection mode with a KRS5 crystal.

\section{Antimicrobial test}

Biocidal resistance of the treated wool fabrics was assessed quantitatively according to AATCC standard test method 100-2004. Wool fabrics were exposed to different species of microorganisms; namely Escherichia Coli AATCC 2666 (gram negative bacteria), Staphylococcus Aureus AATCC 6538 (gram positive 
bacteria) and Candida Albicans AATCC 3736. All species of microorganisms were individually inoculated into tubes containing $5 \mathrm{ml}$ BHIB (Brain Heart Infusion Broth) sterile suspension. The suspension was adjusted spectrophotometrically. A small volume of the mentioned microorganisms' inoculums $(10 \mu \mathrm{l})$ was transferred to a sealed jar containing $1 \mathrm{~g}$ of wool fabric and $50 \mathrm{ml}$ of normal saline, then kept in an incubator at $37^{\circ} \mathrm{C}$ for 24 hours. Ten $\mu 1$ of that solution was transferred on nutrient agar in case of Escherichia coli and Candida Albicans, while dextrose sabouraud was used for Staphylococcus Aureus microbes' count. Antimicrobial activity was assessed as Equation 3:

$$
\text { Reduction percentage }(\%)=\frac{A-B}{A} \times 100
$$

where:

$A=$ number of bacteria colonies on untreated fabric

$B=$ number of bacteria colonies on treated fabric.

Washing fastness test

Treated wool fabric was washed according to the AATCC standard method 61-2009. Treated Wool fabric was washed using $2 \mathrm{~g} / \mathrm{l}$ nonionic surfactant (Egyptol PLM) with 1:50 liquor ratio at $45^{\circ} \mathrm{C}$ for 30 min with occasional shaking. The fabrics were then removed and rinsed thoroughly with warm distilled water several time and left to dry at ambient temperature.

\section{Moth proofing test}

Moth proofing test was carried out according to AATCC Test Method 241977. Treated as well as untreated wool samples were exposed to the moth larvae in a perforated plastic box where every one gram sample is exposed to ten larvae of $10 \mathrm{mg}$ weight and having 25-27 days age. These larvae were placed on the top of the samples in an incubator at $27^{\circ} \mathrm{C}, 55 \%$ humidity and kept in a dark place for 14 days. Then the samples were brushed free of debris and loose fibres and reweighed. The living and dead insects were recorded after the experiment and the percentage of insects mortality were determined. The data was reported relative to untreated wool. The percentage weight loss was calculated according to Equation 4:

$$
\text { Weight loss }(\%)=\frac{W_{1}-W_{2}}{W_{1}} \times 100
$$

where:

$W_{1}$ : weight of the initial wool fabric,

$W_{2}$ : weight of wool fabric after insect exposure

\section{Dyeability test}

Untreated as well as treated wool samples with $2 \%$ and $5 \%$ reactive salicylanilide were dyed with $1 \%$ shade of blue acid dye. The needed amount of the dye was dissolved in water then the solution adjusted at $\mathrm{pH} 4.5$. The dyeing

Egypt. J. Chem. 56, No. 5,6 (2013) 
process of wool samples was carried out at $90^{\circ} \mathrm{C}$ with L:R 1:50 for an hour using a laboratory shaking apparatus (Julabo-Germany). After finishing the dyeing process, the samples were washed using nonionic detergent for $30 \mathrm{~min}$ at $45^{\circ} \mathrm{C}$ and air dried. Finally, spectral reflectance measurements of the dyed wool samples were measured using UV/Vis spectrophotometer (Hunter lab, Ultra Scan Pro, USA). The color values expressed as K/S values of the dyed samples were determined by applying Kubelka-Munk Equation 5: ${ }^{(20)}$

$$
\mathrm{K} / \mathrm{S}=\quad \frac{(1-R)^{2}}{2 R}-\frac{\left(1-R_{0}\right)^{2}}{2 R_{0}}
$$

Where:

$R=$ is the decimal fraction of the reflectance of the dyed substrate $R_{o}=$ is the decimal fraction of the reflectance of the undyed substrate $S=$ is the scattering coefficient, and $\mathrm{K}$ is the absorption coefficient

\section{Results and Discussions}

FTIR of 2-(4,6-dichloro-1,3,5-triazin-2-yloxy)-N-phenylbenzamide

The FTIR spectrum of the chemicals used in the reactive salicylanilide synthesis was examined. Fig.1 shows the results of FTIR analyses for 2,4,6trichloro-1,3,5-triazine (I), salicylanilide (II) and reactive salicylanilide (III).

The reaction between 2,4,6-trichloro-1,3,5-triazine and phenolic-OH group of salicylanilide was approved through the disappearance of the absorption peak of phenolic - $\mathrm{OH}$ group at $1454 \mathrm{~cm}^{-1}$ Figure 1(II) and formation of a new absorption peak at $1179 \mathrm{~cm}^{-1}$ at one time Figure 1(III), which may be referred to the formation of new ether linkage as proposed in Figure 2.

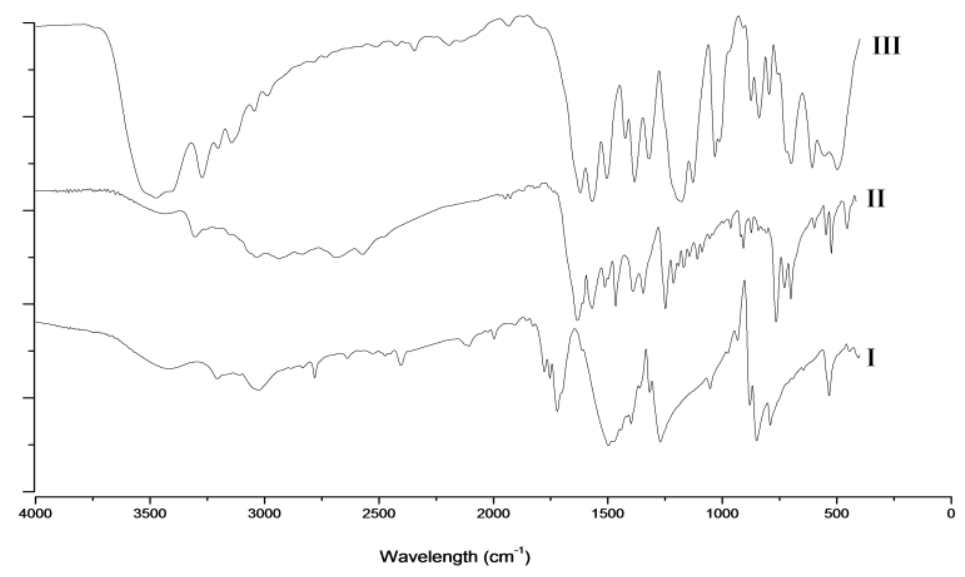

Fig. 1. FTIR spectrum of 2,4,6-trichloro-1,3,5-triazine (I), salicylanilide (II) and reactive salicylanilide (III).

Egypt. J. Chem. 56, No. 5,6 (2013) 


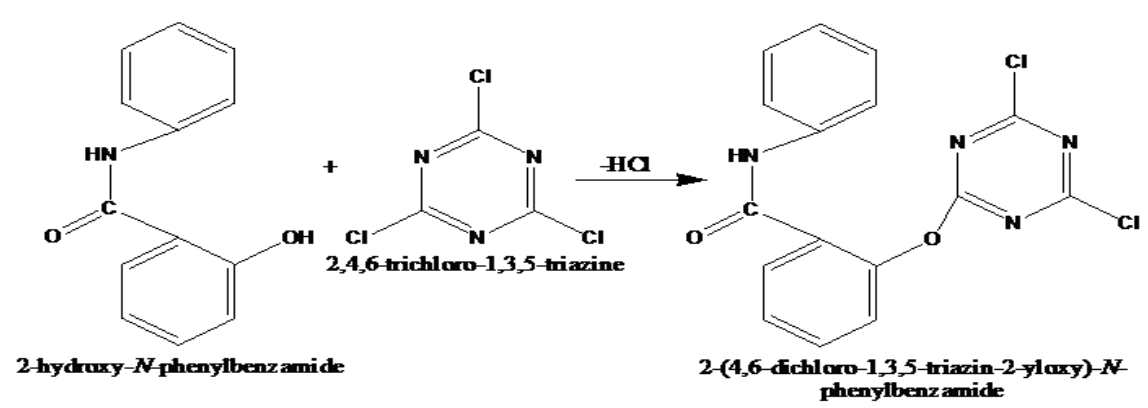

Fig. 2. Proposed reaction between salicylanilide and 2,4,6-Trichloro-1,3,5-triazine to produce reactive salicylanilide.

\section{Effect of reactive salicylanilide concentration}

Wool fabrics were treated with varying concentrations of reactive salicylanilide (1-5\% o.w.f). The add on (\%) to wool fabric is illustrated in Table 1. Data of Table 1 clarifies that as the concentration of reactive salicylanilide increase, the add on (\%) decreases but the $M$ (amount of adsorbed reactive salicylanilide $\mathrm{g} / 100 \mathrm{~g}$ wool fabric) still increase the concentration $2 \%$. Higher concentration of the treatment solution (3-5\%) has no significant effect on the $M$. This indicates that the equilibrium state of the reaction is established at that concentration, where all the available sites on the scoured wool fabric were occupied; Lower concentration will be used in the subsequent investigations of the effect of temperature, $\mathrm{pH}$ and time on $M$ (amount of reactive salicylanilide adsorbed by wool fabric $\mathrm{g} / 100 \mathrm{~g}$ ).

TABLE 1. Effect of reactive salicylanilide concentrations on the amount of reactive salicylanilide adsorbed by wool fabric.

\begin{tabular}{ccc}
\hline $\begin{array}{c}\text { Conc. of salicylanilide } \\
(\% \text { o.w.f) }\end{array}$ & $\begin{array}{c}\text { Add on } \\
(\%)\end{array}$ & $\begin{array}{c}\text { Amount of reactive salicylanilide } \\
\text { absorbed by the fabric }(\boldsymbol{M}) \\
(\mathbf{g} / \mathbf{1 0 0} \mathbf{g} \text { wool) }\end{array}$ \\
\hline 1 & 74.7 & 0.8 \\
2 & 77.8 & 1.6 \\
3 & 47.7 & 1.4 \\
4 & 32.0 & 1.6 \\
5 & 31.1 & 1.6 \\
\hline
\end{tabular}

Treatment conditions: Concentration 1-5\% o.w.f, Time 60 min., Temp. $80{ }^{\circ} \mathrm{C}$, pH 5.

\section{Effect of treatment temperature}

Wool fabrics were treated with $2 \%$ reactive salicylanilide solution at different temperatures $\left(20-60^{\circ} \mathrm{C}\right)$ and the results were tabulated in Table 2. Data of Table 2 illustrate that at low treatment temperature $\left(20-40^{\circ} \mathrm{C}\right)$ there was no increase in $M$, which indicate that the reaction didn't begin at those temperatures. At higher

Egypt. J. Chem. 56, No. 5,6 (2013) 
temperature $\left(50-60^{\circ} \mathrm{C}\right) M$ increased to 1.54 at $50^{\circ} \mathrm{C}$, while at higher temperature there was no appreciable increase of $M(1.56)$.

It is worth noting that, the 2,4,6-trichloro-1,3,5-triazine is able to leach its attached chlorine atoms at different temperatures, initially at $0^{\circ} \mathrm{C}$, the second one at $60^{\circ} \mathrm{C}$ and the last chlorine atom at $80^{\circ} \mathrm{C}$. Data of Table 2 also clarify that the second chlorine atom in tryazine ring can react at lower temperature $\left(50^{\circ} \mathrm{C}\right)$, which can be explained on the basis of the accessibility of the reaction between reactive sites on wool surface with reactive salicylanilide.

TABLE 2. Effect of treatment temperature on the amount of reactive salicylanilide adsorbed by wool fabric

\begin{tabular}{ccc}
\hline $\begin{array}{c}\text { Temperature } \\
\left({ }^{\mathbf{o}} \mathbf{C}\right)\end{array}$ & $\begin{array}{c}\text { Add on } \\
(\boldsymbol{\%})\end{array}$ & $\begin{array}{c}\text { Amount of reactive salicylanilide } \\
\text { absorbed by the fabric }(\boldsymbol{M}) \\
(\mathbf{g} / \mathbf{1 0 0} \mathbf{g} \text { wool })\end{array}$ \\
\hline 20 & 3.1 & 0.1 \\
30 & 7.6 & 0.2 \\
40 & 38.4 & 0.8 \\
50 & 77.1 & 1.5 \\
60 & 77.8 & 1.6 \\
\hline
\end{tabular}

Treatment conditions: Concentration $2 \%$ o.w.f, Temp. $20-60{ }^{\circ} \mathrm{C}$, Time $60 \mathrm{~min}, \mathrm{pH} 5$.

\section{Effect of treatment time}

The effect of different treatment time on $M$ was studied and demonstrated in Table 3. Data of Table 3 demonstrate the effect of different treatment time on the percentage add on of reactive salicylanilide to woolen fabrics. It was found that the percentage add on to wool fabrics reaches its maximum after 60 minutes, on the other hand, $M$ reaches its maximum value 1.54 after 40 min after which, there is no significant increase in $M$.

TABLE 3. Effect of treatment time on the amount of reactive salicylanilide adsorbed by wool fabric

\begin{tabular}{ccc}
\hline $\begin{array}{c}\text { Treatment Time } \\
\text { (Min.) }\end{array}$ & $\begin{array}{c}\text { Add on } \\
(\mathbf{\%})\end{array}$ & $\begin{array}{c}\text { Amount of absorbed reactive } \\
\text { salicylanilide by the fabric }(\boldsymbol{M}) \\
(\mathbf{g} / \mathbf{1 0 0} \mathbf{g} \text { wool) }\end{array}$ \\
\hline 10 & 63.0 & 0.3 \\
20 & 77.6 & 0.7 \\
30 & 81.5 & 1.4 \\
40 & 98.1 & 1.5 \\
50 & 98.7 & 1.5 \\
60 & 99.1 & 1.5 \\
\hline Treatment conditions: Concentration $2 \%$ o.w.f, Temp. $50^{\circ} \mathrm{C}, \mathrm{pH}$ 5, Time 10-60 min.
\end{tabular}

\section{Effect of $p H$}

The reaction between scoured wool fabrics and reactive salicylanilide was carried out at various values of $\mathrm{pH}$, Table 4 . On one hand, the data obtained from Table 4 shows that at $\mathrm{pH}(3-4)$, acidic medium, $M$ values increase. These results attributed to the increase the amount of protonated amino groups on the wool 
fabrics, leading to the increase of active sites on the fabric samples. On the other hand, at $\mathrm{pH}(5-8)$, the protonation of amino groups decreased, which could be the reason behind the deceasing $M$ values.

TABLE 4. Effect of treatment $\mathrm{pH}$ on the amount of reactive salicylanilide adsorbed by wool fabric.

\begin{tabular}{ccc} 
by wool fabric. & $\begin{array}{c}\text { Add on } \\
(\boldsymbol{\%})\end{array}$ & $\begin{array}{c}\text { Amount of reactive salicylanilide absorbed } \\
\text { by the fabric }(\boldsymbol{M}) \\
(\mathbf{g} / \mathbf{1 0 0} \mathbf{~ g ~ w o o l})\end{array}$ \\
\hline 3 & 91.3 & 1.8 \\
4 & 99.1 & 2.0 \\
5 & 76.8 & 1.5 \\
6 & 74.9 & 1.5 \\
7 & 76.7 & 1.5 \\
8 & 66.7 & 1.3 \\
\hline Treatment conditions: Concentration $2 \%$ o.w.f, Time $50 \mathrm{~min}, \mathrm{Temp}, 6{ }^{\circ} \mathrm{C}, \mathrm{pH} 3-8$.
\end{tabular}

\section{Antimicrobial properties}

Treated wool fabrics were challenged against selected species of microorganisms namely; Escherichia Coli (gram-negative bacteria) and Staphylococcus Aureus (gram-positive bacteria) or Candida Albicans. Antimicrobial properties of those fabrics were investigated and the results of which were represented in Table 5.

The microbial resistances of treated wool fabrics depends on the reactive saliycilanilide concentrations, where when the concentration of salicylanilide increases, the resistance of the fabric to bacteria and fungi increases. Data of Table 5 clearly emphasize that the smallest amount of reactive saliycilanilide can inhibit the growth of both gram + ve and gram -ve bacteria with a preferential inhibition in case of Candida Albicans. These results emphasize that saliycilanilide has a great biocidal effect.

TABLE 5. Biocidal effect of treated wool fabrics with different concentration.

\begin{tabular}{cccc}
\hline $\begin{array}{c}\text { Amount of reactive } \\
\text { salicylanilide absorbed } \\
\text { by the fabric }(\boldsymbol{M})\end{array}$ & \multicolumn{3}{c}{$\begin{array}{c}\text { Microbial Reduction } \\
(\boldsymbol{\%})\end{array}$} \\
\cline { 2 - 4 } (g/100 g wool) & $\boldsymbol{E}$. Coli & S. Aureus & C. Albicans \\
\hline Untreated wool fabric & nil & nil & nil \\
0.3 & 56 & 66 & 82 \\
0.7 & 87 & 90 & 96 \\
1.3 & 100 & 100 & 100 \\
1.4 & 100 & 100 & 100 \\
1.5 & 100 & 100 & 100 \\
1.8 & 100 & 100 & 100 \\
2.0 & 100 & 100 & 100 \\
\hline Treatment Conditions: Reactive salicylanilide concentration 2\% & & & \\
$50^{\circ} \mathrm{C}$. & &
\end{tabular}

Egypt. J. Chem. 56, No. 5,6 (2013) 
Washing fastness

The treated wool fabrics were subjected to 10 washing cycles using nonionic surfactant (Egyptol PLM) for $30 \mathrm{~min}$ at $45^{\circ} \mathrm{C}$. It observed that the treated wool fabrics, before and after washing, showed high resistance to the mentioned bacteria and fungus compared to untreated ones. It is found that repeated washing of the treated wool fabrics has no appreciable effect on the permanency of the reactive salicylanilide bonded to wool fabric, the biocidal activity of the fabrics emphasize this result (Table 6). The stability of reactive salicylanilide on the wool fabrics surface is referred to the formation of stable covalent bond between the reactive salicylanilide and wool.

TABLE 6. Biocidal effect of treated wool fabrics with different concentration after 10 washing cycles.

\begin{tabular}{|c|c|c|c|}
\hline \multirow{2}{*}{$\begin{array}{c}\text { Amount of reactive } \\
\text { salicylanilide } \\
\text { absorbed by the } \\
\text { fabric }(M) \\
(\text { g/100 } \mathrm{g} \text { wool }) \\
\end{array}$} & \multicolumn{3}{|c|}{$\begin{array}{l}\text { Microbial Reduction } \\
(\%)\end{array}$} \\
\hline & E. Coli & S. Aureus & C. Albicans \\
\hline Untreated wool fabric & nil & nil & nil \\
\hline 0.3 & 54 & 65 & 82 \\
\hline 0.7 & 85 & 88 & 94 \\
\hline 1.3 & 100 & 100 & 100 \\
\hline 1.4 & 100 & 100 & 100 \\
\hline 1.5 & 100 & 100 & 100 \\
\hline 1.8 & 100 & 100 & 100 \\
\hline 2.0 & 100 & 100 & 100 \\
\hline \multicolumn{4}{|c|}{$\begin{array}{l}\text { Treatment Conditions: reactive salicylanilide concentration } 2 \% \text { o.w.f, } \mathrm{pH} 5 \text {, time } 60 \mathrm{~min} \text {, Temp. } \\
50^{\circ} \mathrm{C} \text {. }\end{array}$} \\
\hline \multicolumn{4}{|c|}{$\begin{array}{l}\text { Moth proofing properties } \\
\text { The resistance of wool fabric treated with reactive salicylanilide to moth larvae } \\
\text { was investigated, and the results were shown in Table } 7 \text {. It was found that unwashed } \\
\text { wool samples treated with reactive salicylanilide gave excellent resistance to moth } \\
\text { larvae compared to control ones. The same result was observed of treated wool } \\
\text { samples washed for } 10 \text { washing cycles, which indicates the stability of covalent bond } \\
\text { formed between reactive salicylanilide and wool fabrics. }\end{array}$} \\
\hline
\end{tabular}

TABLE 7. Resistance of wool fabrics treated with reactive salicylanilide (RS) to moth larvae attack.

\begin{tabular}{lccc}
\hline \multicolumn{1}{c}{ Conditions of treated wool } & $\begin{array}{c}\text { Weight loss } \\
\text { due to moth } \\
(\boldsymbol{\%})\end{array}$ & $\begin{array}{c}\text { Mortality } \\
(\boldsymbol{\%})\end{array}$ & Upgrade \\
\hline Unscoured wool fabric & 15 & nil & Very bad \\
Scoured wool fabric & 12 & 90 & bad \\
Sample treated with RS (unwashed) & 1.1 & 88 & terrific \\
Sample treated with RS (washed 5 times) & 1.7 & 87 & terrific \\
Sample treated with RS (washed 10 times) & 1.1 & 87 & terrific \\
\hline
\end{tabular}

Treatment conditions: reactive salicylanilide concentration $2 \%$ o.w.f, $\mathrm{pH} 5$, time $60 \mathrm{~min}$, temperature $50{ }^{\circ} \mathrm{C}$. 


\section{Dyeability properties}

Wool fabrics, treated with $2 \%$ and $5 \%$ reactive salicylanilide, were subjected to dyeing test with acid dye. The colour values $(\mathrm{K} / \mathrm{S})$ of treated as well as untreated fabrics were measured at different wave lengths and the revealed data (Table 8) are discussed as follows. It is obvious that K/S value of the control sample is higher than that of the treated samples. This is attributed to the occupation of the active cites (pronated amino groups) where the acid dye covalently bonded to the wool samples.

TABLE 8. Dyeability of wool fabrics treated with reactive salicylanilide.

\begin{tabular}{cccc}
\hline \multirow{2}{*}{ Sample } & \multicolumn{3}{c}{ K/S of fabric at different wave length } \\
\cline { 2 - 4 } & 580 & 615 & 630 \\
\hline Blank & 2.4 & 2.7 & 2.0 \\
Treated with 2\% & 2.0 & 2.8 & 1.8 \\
Treated with 5\% & 2.0 & 2.2 & 1.7 \\
\hline
\end{tabular}

Treatment conditions: time $60 \mathrm{~min}$, Temp. $50^{\circ} \mathrm{C}, \mathrm{pH} 4$.

\section{Conclusions}

2-[4,6,-dichloro-1,3,5- triazine-2- yloxy]-N- phenyl benzamide was synthesized by the reaction of 2,4,6-trichloro-1,3,5-triazine with native salicylanilide and the formed reactive salicylanilide was confirmed by FTIR where the disappearance of phenolic hydroxyl group and appearance of new ether linkage were observed. Change of the amount of reactive salicylomilide absorbed by $100 \mathrm{~g}$ wool fabric of wool fabric was varied depending on the reaction conditions the different parameters of reactive salicylanilide. The maximum $M$ is

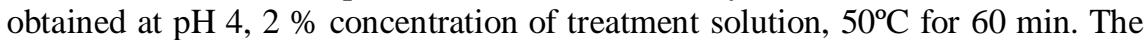
ability of treated fabrics for dyeing was decreased compared to the untreated one. The biocidal activity of the treated wool fabric gave good resistance for the selected species of bacteria and fungi as well as insect resistance even after 10 washing cycles. Treated fabrics inhibite the growth of both Escherichia Coli (gram negative bacteria) and Staphylococcus Aureus (gram positive bacteria) for a great extent. It was found also that the resistance of the treated fabrics to the growth of Candida Albicans fungus was more than that of both classes of bacteria. Finally, the treated fabric show an acceptable resistance to moth larvae for attack.

\section{References}

1. Purwar, R. and Joshi, M. Recent developments in antimicrobial finishing of textiles: a review. AATCC review, 4(3), 22-26(2004).

2. Gao, Y. and Cranston, R., Recent advances in antimicrobial treatments of textiles. Textile Research Journal, 78 (1),60-72 (2008).

Egypt. J. Chem. 56, No. 5,6 (2013) 
3. Sun, G. and $\mathbf{X u}, \mathbf{X}$. Durable and regenerable antimicrobial textiles. Google Patents, (1999).

4. Simoncic, B. and Tomsic, B. Structures of novel antimicrobial agents for textiles: a review. Textile Research Journal, 80(16), 1721-1737(2010).

5. Chapurina, M., Redna, L. Yudanova, T., Khomyakov, K., Cherdyntseva, T. and Netrusov, A., Fabrication of antimicrobial viscose materials with antiadhesive properties. Fibre Chemistry, 36(1), 30-32(2004).

6. Gochel, M., Belly, M. and Knott J., Biodegradation of wool during storage. In: Proceedings of the Eighth International Wool Textile Research Conference on Biodegradation of Wool During Storage. Wool Research Organization of New Zealand, New Zealand. pp.139(1990).

7. Lewin, M. Sello, S.B. and Sello, S., Handbook of Fiber Science and Technology: Functional Finishes. Chemical Processing of Fibers and Fabrics. Volume 2. Part AB, CRC Press (1984).

8. Freddi, G., Arai, T., Colonna, G., Boschi, A. and Tsukada, M., Binding wool and antimicrobial properties of the wool-metal complexes. Journal of Applied Polymer Science, 82(14), 3513-3519(2001).

9. Han, S. and Yang, Y. Antimicrobial activity of wool fabric treated with curcumin. Dyes and Pigments, 64(2), 157-161(2005).

10. Ki, H.Y., Kim, J.H., Kwon, S.C. and Jeong, S.H., A study on multifunctional wool textiles treated with nano-sized silver. Journal of Materials Science, 42(19), 80208024(2007).

11. Taddei, P. Monti, P. Freddi, G., Arai, T. and Tsukada, M., Binding of $\operatorname{Co}($ II) and $\mathrm{Cu}$ (II) cations to chemically modified wool fibers: an IR investigation. Journal of Molecular Structure, 650(1), 105-113(2003).

12. Vigo, T. Protection of textiles from biological attack. Handbook of Fiber Science and Technology, 2, p. 367-427(1983).

13. Wang, S., Hou, W., Wei, L., Jia, H. , Liu, X. and Xu, B., Antibacterial activity of nano-SiO2 antibacterial agent grafted on wool surface. Surface and Coatings Technology, 202(3), 460-465(2007).

14. Zhu, P. and Sun, G., Antimicrobial finshing of wool fabrics using quaternary ammonium salts. Journal of Applied Polymer Science, 93(3), 1037-1041(2004).

15. Fargher, R.G., Galloway, L.D. and Probert, M.E. 16-The inhibitory action of certain substances on the growth of mould fungi. Journal of the Textile Institute Transactions, 21(6), T245-T260(1930).

16. Waisser, K., Matyk, J. Divišová, H., Husakova, P., Kuně̌, J., Klimešová, V., Kaustova, J., Möllmann, U., Dahse, H.M. and Miko, M. Archiv der Pharmazie, 339 (11), 616-620(2006). 
17. Atef El-Sayed, A., Dorgham, S.M. and Kantouch, A., Application of reactive salicylanilide to viscose fabrics as antibacterial and antifungus finishing. International Journal of Biological Macromolecules, 50(1), 273-276(2012).

18. Imramovský, A., Vinšová, J., Férriz, J.M., Buchta, V. and Jampílek, J., Salicylanilide esters of N-protected amino acids as novel antimirobioal agents. Bioorganic \& Medicinal Chemistry Letters, 19(2), 348-351(2009).

19. Vinsova, J. , Imramovsky, A., Buchta, V., Ceckova, M., Dolezal, M., Staud, F., Jampilek, J. and Kaustova, J., Salicylanilide acetates: synthesis and antibacterial evaluation. Molecules, 12(1), 1-12(2008).

20. Judd, D.B. and Wyszecki, G., Color in Business,Science and Industry. John Wiley and Sons: New York (1975).

(Received 10/6/2013;

accepted 10/2/2014) 


\section{اكساب الأقشثة الصوفية مقاومة بيولوجية باستخدام مشتقات الساليسيلانيليا}

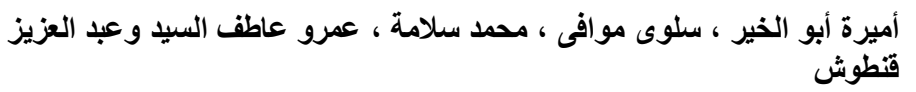

بعد إنتاج الأقمشة ذات الدقاومة البيولوجية للكائنات الدقيقة و التى تعتبر من من من من

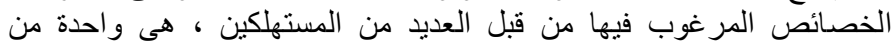

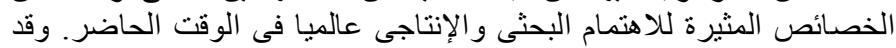

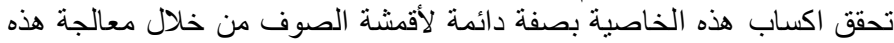

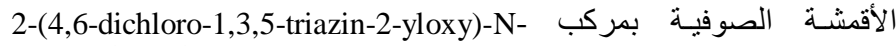

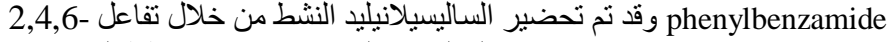
مع الساليسيلانيليد. وتم وضع مخطط لميكانيكية

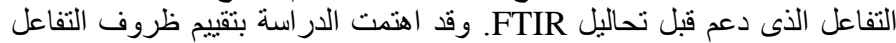

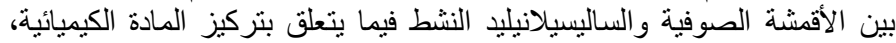

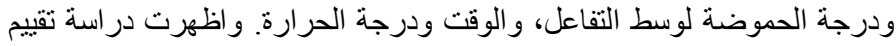

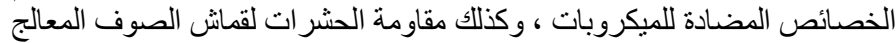

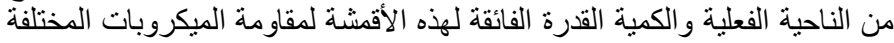
وكذلك حشرة العتة. كما الظهرت الدراسة قدرة هذه الاقمشة على الألى الاحتفاظ بمقاو متها للميكروبات بعد الغسيل المتكرر . 